\title{
Identification of dragon fruit (Selenicereus) species in Mekong Delta based on DNA barcode sequences
}

\author{
TRAN GIA HUY ${ }^{1}$, TRAN THANH MEN ${ }^{2}$, NGUYEN PHAM ANH THI ${ }^{1}$, DO TAN KHANG ${ }^{1, \vartheta}$ \\ ${ }^{1}$ Department of Molecular Biotechnology, Biotechnology Research and Development Institute, Can Tho University. 3/2 Street, Ninh Kieu District, Can \\ Tho City, Viet Nam. Tel./fax. +84-919-813035, vemail: dtkhang@ctu.edu.vn \\ ${ }^{2}$ Department of Biology, School of Natural Sciences, Can Tho University. 3/2 Street, Ninh Kieu District, Can Tho City, Viet Nam
}

Manuscript received: 11 August 2021. Revision accepted: 18 September 2021.

\begin{abstract}
Huy TG, Men TT, Thi NPA, Khang DT. 2021. Identification of dragon fruit (Selenicereus) species in Mekong Delta based on DNA barcode sequences. Biodiversitas 22: 4216-4222. Selenicereus species is one of the valuable fruiting plants in Vietnam due to its properties, e.g., rich nutrition and medicine activity. Eight DNA barcodes applied to the discrimination power of dragon fruit species in the Mekong delta. Total DNA extracted from fresh roots and the loci of interest were amplified and sequenced. DNA sequences were aligned and determined variable regions. The findings revealed that four loci, including $m a t \mathrm{~K}, r b c \mathrm{~L}, r p o \mathrm{C} 1$, and $a t p \mathrm{~F}-\mathrm{H}$ reached high PCR yield and specificity compared to those in $y c f 1 \mathrm{~b}, p s b \mathrm{~K}-\mathrm{I}$, and ITS. The atpF-H was the most variable region due to the number of single nucleotide polymorphisms (SNPs) and indel mutations, whereas $r p o \mathrm{C} 1$ was the least one. Based on sequence characteristics, each locus only discriminated some of the Selenicereus monacanthus from Southern Horticultural Research Institute identified by combining three loci, $a t p \mathrm{~F}-\mathrm{H}, m a t \mathrm{~K}$, and $r b c \mathrm{~L}$. The results elucidated the close genetic relationship between Mekong delta dragon fruits and National Center for Biotechnology Information (NCBI) database. Furthermore, this finding generated a DNA barcode database of ten dragon fruit accessions and suggested that multiple loci in the chloroplast genome should be a reliable solution for identifying this highly commercial fruiting plant.
\end{abstract}

Keywords: atpF-H, matK, plant authentication, $r b c \mathrm{~L}$, Selenicereus

\section{INTRODUCTION}

Selenicereus (A. Berger) Britton \& Rose, pitahaya or dragon fruit, belongs to the family Cactaceae, is distributed from South America regions. Individuals of this genus are described as vine cacti with unique traits such as climbing, aerial roots, three angled stems, and glabrous large-scaled berry (Montoya-Arroyo et al. 2014). It is grown as ornamental plants in gardens and indoors for its size, aromatic, and abnormal time blooming flowers. At present, dragon fruits are being exported globally and have a high economic value as exotic fruit crops in harsh regions where water is limited. The Crassulacean acid metabolism pathway is utilized for carbon dioxide fixation and is highly tolerant to water stress (Ibrahim et al. 2018). The fruits have played a remarkable role in medicine, food, and ornamentally. Dragon fruit is rich in essential nutrients such as vitamins, minerals, complex carbohydrates, dietary fibers, and antioxidants (Wichienchot et al. 2010; Tenore et al. 2012). Dragon fruit can withstand prolonged drought. Therefore, it considers as a high potential fruit for horticultural development, especially in areas where drought is a limiting factor for other fruits. There are 14 species of dragon fruit in the world (Cisneros and Tel-Zur 2012). White flesh dragon fruit (Selenicereus undatus) and red flesh dragon fruit (Selenicereus monacanthus) cultivate in Vietnam. To the best of our knowledge, dragon fruits were classified into the Selenicereus genus base on DNA sequences in both nuclear and plastid (Korotkova et al.
2017). Thus, the accepted scientific name of dragon fruit is Selenicereus instead of Hylocereus.

DNA barcodes are short DNA fragments, around 400$800 \mathrm{bp}$, found in all plant species (DeSalle and Goldstein 2019). DNA is a specialized chain of "letters" that distinguish between organisms and/or individuals despite very similar morphological features between them. By integrating the advances of molecular biology, sequencing technologies, and bioinformatics, DNA barcodes provide a quick and accurate means to recognize previously known, described, and classified species and construct a DNA database for them (Kress 2017). As a result of the low nucleotide substitution rate in land plants, it is a challenge to determine a standard DNA barcode (Fazekas et al. 2012). Furthermore, several loci from the plastid genome analyze for species discrimination power. Two genes of $m a t \mathrm{~K}$ and $r b c \mathrm{~L}$ and their combination proposed as a standard DNA barcode for land plants (DeSalle and Goldstein 2019).

In Selenicereus species, some studies focused on the morphology and Inter-simple sequence repeat (ISSR marker) for genetic diversity and species identification (Tao et al. 2014; Abirami et al. 2021). However, morphological traits influenced by environmental factors and the band pattern may not be reliable because ISSR is a dominant marker. Based on nucleotide sequences, which is environment independence, DNA barcodes proposed a potential solution for plant authentication. This current study was to disclose the ability of DNA barcodes to identify Selenicereus species in The Mekong delta. 


\section{MATERIALS AND METHODS}

\section{Plant sampling}

Ten samples of Selenicereus species were collected from Southern Horticultural Research Institute (SOFRI) and fruit gardens in The Mekong delta (Table 1). The $S$. monacanthus DF1 was the high yield variety cultivated ubiquitously in The Mekong delta. Such samples were verified by SOFRI staff.

\section{DNA extraction and amplification}

Fresh roots sterilized with $70 \%$ ethanol and then cut into tiny pieces. Samples were incubated at liquid nitrogen for 5 minutes and grind into powder. Total DNA was extracted using the CTAB-based protocol (Roger and Bendich 1988) with appropriate modifications. The quantity and purity of DNA were measured by Nanodrop spectrophotometer 2000C (Thermo Scientific, USA). DNA integrity was examined by $1 \%$ agarose electrophoresis.

Eight loci, including four genes matK, $r p o \mathrm{C} 1, r b c \mathrm{~L}$, $y c f 1 \mathrm{~b}$, and four noncoding spacers $p s b \mathrm{~A}-\operatorname{trnH}$, atp $\mathrm{F}-\mathrm{H}$, $p s b \mathrm{~K}-\mathrm{I}$, ITS were amplified by $30 \mu \mathrm{L}$ of volume reaction. The reagents consist of $15 \mu \mathrm{L}$ of master mix $2 \mathrm{X}$ (Bioline, United Kingdom), $0.4 \mu \mathrm{M}$ of each forward and reverse primer, and DNA template. Primer sequences are listed in Table 2. The amplification process was performed in C1000 thermocycler (Bio-rad, USA) (Table 2). PCR products were separated by $2 \%$ agarose electrophoresis for 45 minutes at $50 \mathrm{~V}$, and the bands were visualized by RunSafe stain (Cleaver Scientific, United Kingdom). Amplicons with clear bands and no nonspecific products were submitted to Nextgen Biotechnology corporation for sequencing (3500 Genetic Analyzer, Applied Biosystem).

Table 1. Main characteristics of ten dragon fruit samples in this study

\begin{tabular}{|c|c|c|c|c|c|c|c|}
\hline Code & Species & Shape & Source & Code & Species & Shape & Source \\
\hline DF1 & S. monacanthus & Red flesh, oval fruit & $\begin{array}{l}\text { SOFRI, } \\
\text { cultivated }\end{array}$ & DF6 & S. undatus & $\begin{array}{l}\text { White flesh, } \\
\text { oval fruit }\end{array}$ & $\begin{array}{l}\text { Ben Tre, } \\
\text { cultivated }\end{array}$ \\
\hline DF2 & S. monacanthus & Red flesh, oval fruit & $\begin{array}{l}\text { Ben Tre, } \\
\text { cultivated }\end{array}$ & DF7 & S. undatus & $\begin{array}{l}\text { White flesh, } \\
\text { oval fruit }\end{array}$ & $\begin{array}{l}\text { Ca Mau, } \\
\text { cultivated }\end{array}$ \\
\hline DF3 & S. monacanthus & Red flesh, oval fruit & $\begin{array}{l}\text { Ca Mau, } \\
\text { cultivated }\end{array}$ & DF8 & S. megalanthus & $\begin{array}{l}\text { Yellow skin, } \\
\text { white flesh, } \\
\text { oval fruit }\end{array}$ & $\begin{array}{l}\text { Dong Thap, } \\
\text { cultivated }\end{array}$ \\
\hline DF4 & Selenicereus sp. & Red flesh, round fruit & $\begin{array}{l}\mathrm{Ca} \mathrm{Mau,} \\
\text { cultivated }\end{array}$ & DF9 & S. megalanthus & $\begin{array}{l}\text { Yellow skin, } \\
\text { white flesh, } \\
\text { oval fruit }\end{array}$ & $\begin{array}{l}\text { Tien Giang, } \\
\text { cultivated }\end{array}$ \\
\hline DF5 & Selenicereus sp. & Purple flesh, oval fruit & $\begin{array}{l}\text { SOFRI, } \\
\text { cultivated }\end{array}$ & DF10 & Selenicereus sp. & Not available & $\begin{array}{l}\text { An Giang, } \\
\text { wild }\end{array}$ \\
\hline
\end{tabular}

Note: DF1: S. monacanthus SORFI; DF2: S. monacanthus BT, DF3: S. monacanthus CM; DF4: Selenicereus sp.; DF5: Selenicereus sp. SORFI; DF6: S. undatus BT; DF7: S. undatus CM; DF8: S. megalanthus DT; DF9: S. megalanthus TG; DF10: Selenicereus sp. AG.

Table 2. Nucleotide sequences of primer pairs for amplification of DNA barcode candidates (Primer database from boldsystems.org)

\begin{tabular}{|c|c|c|}
\hline Locus & Sequence (5'-3') & Thermal cycle ( 35 cycles) \\
\hline matK & $\begin{array}{l}\text { F: CGATCTATTCATTCAATATTTC } \\
\text { R: TCTAGCACACGAAAGTCGAAGT }\end{array}$ & $\begin{array}{l}94^{\circ} \mathrm{C}-1 \mathrm{~min} ; 94^{\circ} \mathrm{C}-30 \mathrm{sec}, 50^{\circ} \mathrm{C}-40 \mathrm{sec}, 72^{\circ} \mathrm{C}-40 \mathrm{sec} ; \\
72^{\circ} \mathrm{C}-5 \mathrm{~min}\end{array}$ \\
\hline$r b c \mathrm{~L}$ & $\begin{array}{l}\text { F: ATGTCACCACAAACAGAGACTAAAGC } \\
\text { R: GTAAAATCAAGTCCACCRCG }\end{array}$ & \multirow{2}{*}{$\begin{array}{l}94^{\circ} \mathrm{C}-4 \mathrm{~min} ; 94^{\circ} \mathrm{C}-30 \mathrm{sec}, 55^{\circ} \mathrm{C}-30 \mathrm{sec}, 72^{\circ} \mathrm{C}-1 \mathrm{~min} ; \\
72^{\circ} \mathrm{C}-10 \mathrm{~min}\end{array}$} \\
\hline$p s b \mathrm{~A}-t r n \mathrm{H}$ & $\begin{array}{l}\text { F: GTTATGCATGAACGTAATGCTC } \\
\text { R: CGCGCATGGTGGATTCACAATCC }\end{array}$ & \\
\hline rpoC1 & $\begin{array}{l}\text { F: GGCAAAGAGGGAAGATTTCG } \\
\text { R: CCATAAGCATATCTTGAGTTGG }\end{array}$ & $\begin{array}{l}94^{\circ} \mathrm{C}-4 \mathrm{~min} ; 94^{\circ} \mathrm{C}-30 \mathrm{sec}, 58^{\circ} \mathrm{C}-30 \mathrm{sec}, 72^{\circ} \mathrm{C}-1 \mathrm{~min} ; \\
72^{\circ} \mathrm{C}-10 \mathrm{~min}\end{array}$ \\
\hline atp $\mathrm{F}-a t p \mathrm{H}$ & $\begin{array}{l}\text { F: ACTCGCACACACTCCCTTTCC } \\
\text { R: GCTTTTATGGAAGCTTTAACAAT }\end{array}$ & \multirow{2}{*}{$\begin{array}{l}94^{\circ} \mathrm{C}-4 \mathrm{~min} ; 94^{\circ} \mathrm{C}-30 \mathrm{sec}, 51^{\circ} \mathrm{C}-40 \mathrm{sec}, 72^{\circ} \mathrm{C}-40 \mathrm{sec} \text {; } \\
72^{\circ} \mathrm{C}-5 \mathrm{~min}\end{array}$} \\
\hline$p s b \mathrm{~K}-p s b \mathrm{I}$ & $\begin{array}{l}\text { F: TTAGCCTTTGTTTGGCAAG } \\
\text { R: TTAGCCTTTGTTTGGCAAG }\end{array}$ & \\
\hline ITS & $\begin{array}{l}\text { F: TCCGGGAACCTGCGG } \\
\text { R: TCCTCCGCTTTGATGC }\end{array}$ & $\begin{array}{l}95^{\circ} \mathrm{C}-5 \mathrm{~min} ; 95^{\circ} \mathrm{C}-30 \mathrm{sec}, 57^{\circ} \mathrm{C}-30 \mathrm{sec}, 72^{\circ} \mathrm{C}-1 \mathrm{~min} ; \\
72^{\circ} \mathrm{C}-5 \mathrm{~min}\end{array}$ \\
\hline$y c f 1 \mathrm{~b}$ & $\begin{array}{l}\text { F: TCTCGACGAAAATCAGATTGTTGTGAAT } \\
\text { R: ATACATGTCAAGTGATGGAAAA }\end{array}$ & $\begin{array}{l}95^{\circ} \mathrm{C}-5 \mathrm{~min} ; 95^{\circ} \mathrm{C}-30 \mathrm{sec}, 51^{\circ} \mathrm{C}-40 \mathrm{sec}, 72^{\circ} \mathrm{C}-1 \mathrm{~min} ; \\
72^{\circ} \mathrm{C}-10 \mathrm{~min}\end{array}$ \\
\hline
\end{tabular}


Table 3. Accession numbers for DNA barcode sequences in this study

\begin{tabular}{|c|c|c|c|c|}
\hline Samples & atpF-H & $r b c \mathbf{L}$ & rpoC1 & matK \\
\hline DF1 & OK094559 & OK094539 & OK094549 & OK094529 \\
\hline DF2 & OK094560 & OK094540 & OK094550 & OK094530 \\
\hline DF3 & OK094561 & OK094541 & OK094551 & OK094531 \\
\hline DF4 & OK094562 & OK094542 & OK094552 & OK094532 \\
\hline DF5 & OK094563 & OK094543 & OK094553 & OK094533 \\
\hline DF6 & OK094564 & OK094544 & OK094554 & OK094534 \\
\hline DF7 & OK094565 & OK094545 & OK094555 & OK094535 \\
\hline DF8 & OK094566 & OK094546 & OK094556 & OK094536 \\
\hline DF9 & OK094567 & OK094547 & OK094557 & OK094537 \\
\hline DF10 & OK094568 & OK094548 & OK094558 & OK094538 \\
\hline
\end{tabular}

Note: DF1: S. monacanthus SORFI; DF2: S. monacanthus BT, DF3: S. monacanthus CM; DF4: Selenicereus sp.; DF5: Selenicereus sp. SORFI; DF6: S. undatus BT; DF7: S. undatus CM; DF8: S. megalanthus DT; DF9: S. megalanthus TG; DF10: Selenicereus sp. AG

\section{Data analysis}

Raw sequences were interpreted by Bioedit software version 7.2.1. The quality value checks to confirm the accuracy of the sequencing procedure, and unidentified nucleotide was verified based on the chromatogram. These sequences were submitted to Genbank for accession number registration (Table 3). Multiple sequence alignment was conducted by following the ClustalW algorithm. Conservative and variable regions determine by MEGA $X$ software (Kumar et al. 2018). Homologous sequences belong to the Selenicereus genus on Nation Center Biotechnology Information (NCBI) were collected by Basic Local Alignment Search Tool (BLAST).

\section{RESULTS AND DISCUSSION}

\section{Amplification of DNA barcode sequences}

Eight DNA barcode sequences, including four proteinencoding genes $(y c f 1 \mathrm{~b}, r b c \mathrm{~L}, r p o \mathrm{C} 1$, and $m a t \mathrm{~K})$ and four non-coding sequences (atpF-H, psbA-trn $\mathrm{H}, p s b \mathrm{~K}-\mathrm{I}$, and ITS), were amplified and visualized on the gel (Figure 1). From the gel patterns, amplicon size ranged from 400 to 900 bp for eight loci. It indicated that three genes rpoC1, $r b c \mathrm{~L}, m a t \mathrm{~K}$, and two spacers atpF-H, psbA-trn $\mathrm{H}$ showed unique bands, reflecting the PCR specificity. No band has appeared in the negative control sample, indicating that external contamination under-controlled. Therefore, such five loci were suitable to sequence and analyze species identification. On the other hand, the presence of nonspecific bands from the $y c f 1 \mathrm{~b}$ gene, ITS, and $p s b \mathrm{~K}-\mathrm{I}$ spacer made such loci unsuitable for sequencing.

\section{Sequence analysis for DNA barcode candidates}

Based on the chromatogram, the quality value of DNA sequences was verified. The psbA-trn $\mathrm{H}$ spacer indicated multiple unidentified characters while atp $\mathrm{F}-\mathrm{H}, m a t \mathrm{~K}$, rpo $\mathrm{C} 1$, and $r b c \mathrm{~L}$ expressed clear nucleotide signals. Conservative and variable sites of such loci were detected based on multiple sequence alignment (Table 4). Based on the alignment result, all sequences showed a high amount of conserved sites. As a result, Selenicereus species expressed a close genetic relationship. However, the occurrence of SNPs and indel-mutations revealed the nucleotide diversity of such dragon fruit species. The atpF$\mathrm{H}$ spacer was the highest variable locus with six variable sites. By contrast, three genes consist of $m a t \mathrm{~K}, \operatorname{rpo} \mathrm{C} 1$, and $r b c \mathrm{~L}$ were highly similar. In terms of indel-mutations, nine mutations were detected from the atpF-H sequence, while the frequency of this mutation was quite low in three other loci. Thus, it could suggest that the noncoding sequence was more variable than coding sequences and proposed as a potential barcode sequence for species discrimination.

A serial insertion of 9 nucleotides ATTAGGTAC was found on Selenicereus sp. DF4 (red flesh and round fruit) (Table 5). Because of this mutation, DF4 distinguish from other red flesh dragon fruits. This result confirmed that atp F-H spacer was highly polymorphic and able to identify this dragon fruit variety. Santos and Pereira (2018) analyzed more than 44,000 sequences belonging to 206 different plant families. Their findings suggested that the $a t p \mathrm{~F}-\mathrm{H}$ spacer was a suitable region for SPInDel (Species Identification by Insertions/Deletions) concept. Furthermore, five substitution mutations were detected and classified into three SNPs as T/C, C/A, and G/A.

Sequence analysis from the $r b c \mathrm{~L}$ gene reflected that this plastid gene was valuable for species delimitation (Table 6). The S. monacanthus DF1 (red flesh) and Selenicereus sp. DF5 (purple flesh) from SOFRI were identified successfully from the other samples by four valuable SNPs, including $\mathrm{G} / \mathrm{C}, \mathrm{A} / \mathrm{C}, \mathrm{G} / \mathrm{T}$, and $\mathrm{T} / \mathrm{C}$, and two consecutive insertions with $\mathrm{A}$ and $\mathrm{G}$. The $r b c \mathrm{~L}$ gene was also evaluated as a hypervariable region, which is the promising DNA barcode to identify $S$. monacanthus and three species $S$. annthonyanus, S. grandifloras and S. validus (Qin et al. 2021).

The rpoC1 gene, a coding sequence in the plastid genome, revealed the incorrect identification of dragon fruits (Table 7). For instance, samples DF1, DF2, and DF3 belonged to $S$. monacanthus, but their sequence was variable. Furthermore, four individuals DF1, DF5, DF6, and DF10 were different species, and their nucleotide sequences were identical. Although rpoC1 was one of 10 informative markers for phylogeny in Cactaceae (Köhler et al. 2020), this plastid gene was not a suitable barcode for Selenicereus species. 


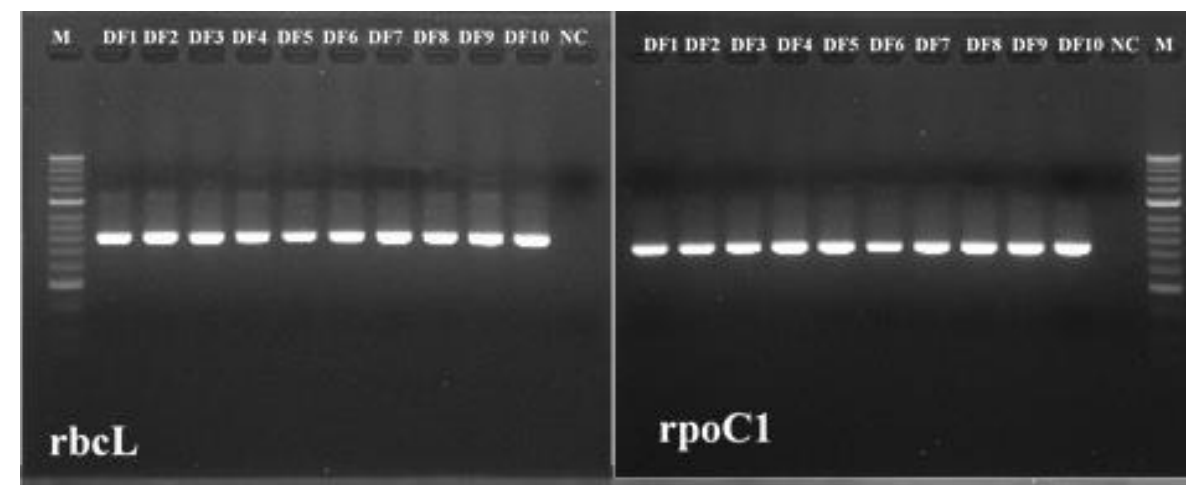

M. DF1 DF2 DF3 DF4 DF5 DF6 DF7 DF8 DF9 NC DF10

M DFI DF2 DF3 DF4 DF5 DF6 BF- DF3 DF9 DFIO NC
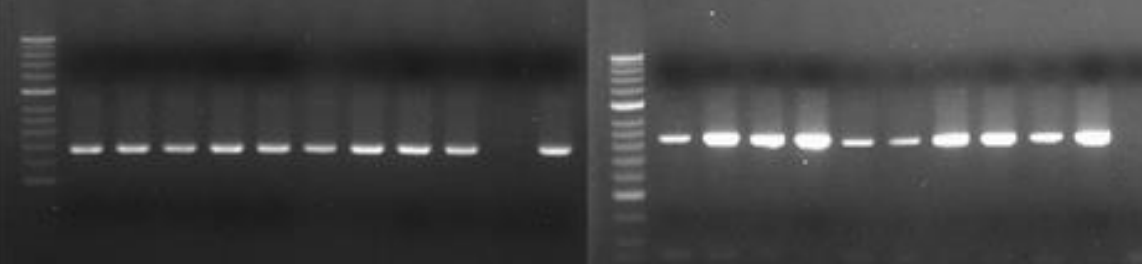

\section{psbA-trnH}

\section{atpF-H}

Y DF1 DF2 DF3 DF4 DF5 DF6 DF7 DF8 DF9 DF10 NC
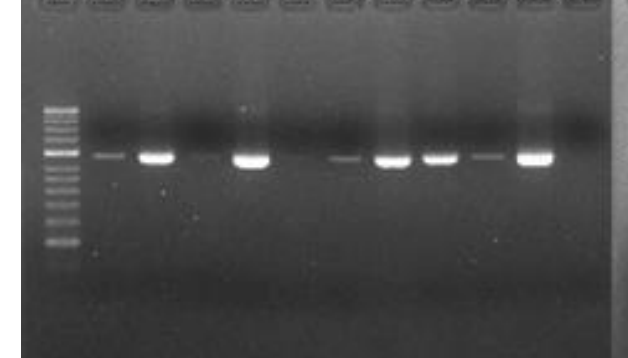

matK

\section{yef1b}

M. DFI DF2 DF3 DF4 DFE DF6 DF7. DF8 DF9 DFIO NC

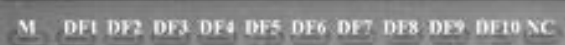
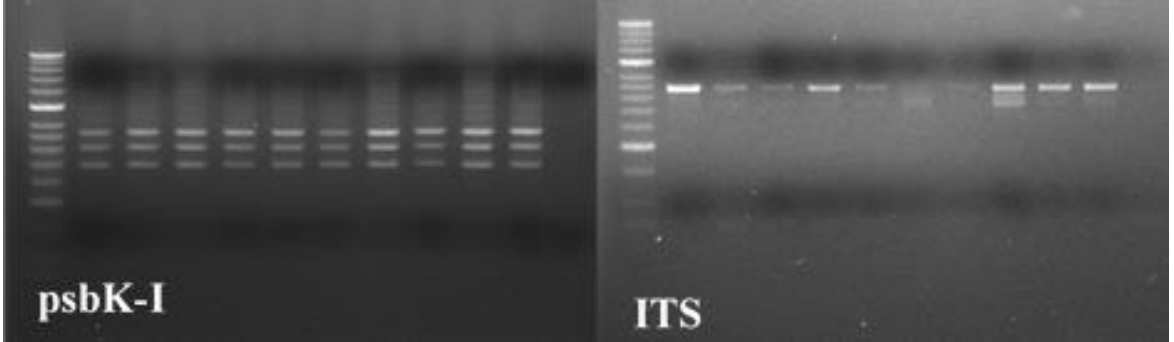

Figure 1. Amplicons of eight DNA barcode locus on 2\% agarose gel. Note: M: 50 bp hyperladder (Bioline, England); DF1: $S$. monacanthus SOFRI; DF2: S. monacanthus BT, DF3: S. monacanthus CM; DF4: Selenicereus sp.; DF5: Selenicereus sp. SOFRI; DF6: S. undatus BT; DF7: S. undatus CM; DF8: S. megalanthus DT; DF9: S. megalanthus TG; DF10: Selenicereus sp. AG; NC: Negative control.

Table 4. Sequence characteristics of four DNA barcode candidates

\begin{tabular}{cccccc}
\hline \multirow{2}{*}{ Locus } & $\begin{array}{c}\text { Aligned length } \\
\text { (bp) }\end{array}$ & $\begin{array}{c}\text { Conserved } \\
\text { sites }\end{array}$ & Singleton sites & $\begin{array}{c}\text { Parsimony informative } \\
\text { sites }\end{array}$ & Indel mutations \\
\cline { 4 - 5 } & 585 & 571 & $5(0.85 \%)$ & $1(0.17 \%)$ & $9(1.54 \%)$ \\
$m a t \mathrm{~F}-\mathrm{H}$ & 782 & 778 & $1(0.13 \%)$ & $3(0.38 \%)$ & $0(0 \%)$ \\
$r b c \mathrm{~L}$ & 506 & 502 & $1(0.20 \%)$ & $3(0.59 \%)$ & $2(0.40 \%)$ \\
$r p o \mathrm{C} 1$ & 452 & 450 & $1(0.22 \%)$ & $1(0.22 \%)$ & $2(0.44 \%)$ \\
\hline
\end{tabular}


Table 5. Single nucleotide polymorphisms (SNPs) and indel mutations of atpF-H spacer

\begin{tabular}{|c|c|c|c|c|c|c|c|c|c|c|c|c|c|c|c|c|}
\hline \multirow{4}{*}{$\begin{array}{c}\text { Accession } \\
\text { number }\end{array}$} & \multirow{4}{*}{ Samples } & \multicolumn{15}{|c|}{ Position } \\
\hline & & 1 & 1 & 1 & 1 & 2 & 2 & 2 & 2 & 2 & 2 & 2 & 2 & 2 & 4 & 5 \\
\hline & & 8 & 8 & 8 & 8 & 7 & 7 & 8 & 8 & 8 & 8 & 8 & 8 & 8 & 9 & 9 \\
\hline & & 1 & 2 & 3 & 4 & 8 & 9 & $\mathbf{0}$ & 1 & 2 & 3 & 4 & 5 & 6 & 5 & 7 \\
\hline OK094559 & DF1 & $\mathbf{T}$ & $\mathbf{T}$ & $\mathbf{T}$ & G & _- & _ & - & _- & - & - & _- & _ & - & $\mathbf{C}$ & $\mathbf{T}$ \\
\hline OK094560 & DF2 & . & . & . & . & - & - & - & - & - & - & - & - & - & . & . \\
\hline OK094561 & DF3 & . & . & . & . & - & - & - & - & - & - & - & - & - & . & . \\
\hline OK094562 & DF4 & C & $\mathbf{A}$ & $\mathbf{A}$ & $\mathbf{A}$ & $\overline{\mathbf{A}}$ & $\overline{\mathbf{T}}$ & $\overline{\mathbf{T}}$ & $\overline{\mathbf{A}}$ & $\overline{\mathbf{G}}$ & $\overline{\mathbf{G}}$ & $\overline{\mathbf{T}}$ & $\overline{\mathbf{A}}$ & $\overline{\mathbf{C}}$ & $\mathbf{A}$ & $\mathbf{C}$ \\
\hline OK094563 & DF5 & . & . & . & . & _ & - & - & - & - & - & - & - & - & . & . \\
\hline OK094564 & DF6 & . & . & . & . & - & - & - & - & - & - & - & - & - & . & . \\
\hline OK094565 & DF7 & . & . & . & . & - & - & - & - & - & - & - & - & - & . & C \\
\hline OK094566 & DF8 & . & . & . & . & - & - & - & - & - & - & - & - & - & . & . \\
\hline OK094567 & DF9 & . & . & . & . & - & - & - & - & - & - & - & - & - & . & . \\
\hline OK094568 & DF10 & . & . & . & . & - & - & - & - & - & - & - & - & - & . & . \\
\hline
\end{tabular}

Note: DF1: S. monacanthus SORFI; DF2: S. monacanthus BT, DF3: S. monacanthus CM; DF4: Selenicereus sp.; DF5: Selenicereus sp. SORFI; DF6: S. undatus BT; DF7: S. undatus CM; DF8: S. megalanthus DT; DF9: S. megalanthus TG; DF10: Selenicereus sp. AG.

Table 6. Single nucleotide polymorphisms (SNPs) and indel mutations of $r b c \mathrm{~L}$ gene

\begin{tabular}{|c|c|c|c|c|c|c|c|}
\hline \multirow{2}{*}{$\begin{array}{c}\text { Accession } \\
\text { number }\end{array}$} & \multirow{2}{*}{ Sample } & \multicolumn{6}{|c|}{ Positions } \\
\hline & & 194 & 241 & 489 & 490 & 491 & 492 \\
\hline OK094539 & DF1 & G & $\mathbf{A}$ & $\mathbf{A}$ & G & $\mathbf{G}$ & $\mathbf{T}$ \\
\hline OK094540 & DF2 & . & C & - & - & . & . \\
\hline OK094541 & DF3 & . & C & _ & _- & . & . \\
\hline OK094542 & DF4 & . & $\mathrm{C}$ & - & - & . & . \\
\hline OK094543 & DF5 & . & . & . & . & . & . \\
\hline OK094544 & DF6 & C & . & _ & . & $\mathbf{T}$ & C \\
\hline OK094545 & DF7 & . & C & _ & - & - & . \\
\hline OK094546 & DF8 & . & . & _ & _ & . & . \\
\hline OK094547 & DF9 & . & . & _ & _ & . & . \\
\hline OK094548 & DF10 & . & C & & & . & . \\
\hline
\end{tabular}

Note: DF1: S. monacanthus SORFI; DF2: $S$. monacanthus BT, DF3: S. monacanthus CM; DF4: Selenicereus sp.; DF5: Selenicereus sp. SORFI; DF6: S. undatus BT; DF7: S. undatus CM; DF8: S. megalanthus DT; DF9: S. megalanthus TG; DF10: Selenicereus sp. AG.

It illustrated that the mat $\mathrm{K}$ sequence showed nucleotide polymorphism; however, this gene was non-informative to identify dragon fruits species (Table 8). Data from six dragon fruits species from Northern Vietnam (Huong et al. 2021) also showed that the matK gene contained variable sites, but these nucleotides could not discriminate against a particular species. On the other hand, the deletion of adenine in Selenicereus sp. DF5 compared to $S$. monacanthus DF1 SOFRI (position 817) made these two varieties distinguishable.

In comparison with dragon fruit sequences from the NCBI database, it showed that five species, $S$. undatus (NC_053698.1), S. tricae (LT745724.1), S. ocamponis (LT745687.1) (Korotkova et al. 2017), S. costaricensis (JQ590992.1) and S. peruvianus (AY015310.1) showed the identity percent ranging from $97-100 \%$ compared with the S. monacanthus SOFRI (Table 9). Selenicereus costaricensis is the purple flesh dragon fruit variety in Costa Rica (Viñas and Jiménez 2016), this species contained a high amount of bioactive compounds with no
Table 7. Single nucleotide polymorphisms (SNPs) and indel mutations of rpoC1 gene

\begin{tabular}{|c|c|c|c|c|c|}
\hline \multirow{2}{*}{$\begin{array}{c}\text { Accession } \\
\text { number }\end{array}$} & \multirow{2}{*}{ Sample } & \multicolumn{4}{|c|}{ Positions } \\
\hline & & 2 & 4 & 6 & 18 \\
\hline OK094549 & DF1 & $\mathbf{A}$ & $\mathbf{T}$ & $\mathbf{A}$ & $\mathbf{A}$ \\
\hline OK094550 & DF2 & $\mathrm{C}$ & . & - & _ \\
\hline OK094551 & DF3 & . & - & . & - \\
\hline OK094552 & DF4 & . & . & . & - \\
\hline OK094553 & DF5 & . & . & . & . \\
\hline OK094554 & DF6 & - & - & . & . \\
\hline OK094555 & DF7 & $\mathrm{C}$ & G & . & _ \\
\hline OK094556 & DF8 & $\mathrm{C}$ & - & _ & - \\
\hline OK094557 & DF9 & . & . & . & . \\
\hline OK094558 & DF10 & . & . & . & . \\
\hline
\end{tabular}

Note: DF1: S. monacanthus SORFI; DF2: S. monacanthus BT, DF3: S. monacanthus CM; DF4: Selenicereus sp.; DF5: Selenicereus sp. SORFI; DF6: $S$. undatus BT; DF7: S. undatus CM; DF8: S. megalanthus DT; DF9: S. megalanthus TG; DF10: Selenicereus sp. AG.

cytotoxic effects (Paśko et al. 2021). Selenicereus tricae are the wild dragon fruit variety in Belize (GómezHinostrosa et al. 2014) and S. ocamponis is the red flesh dragon fruit variety in Mexico (Ibrahim et al. 2018). The high identity percentage indicated a close genetic relationship among these accessions with $S$. monacanthus SOFRI. Based on sequence similarity, three loci, including mat $\mathrm{K}, a t p \mathrm{~F}-\mathrm{H}$, and $r b c \mathrm{~L}$ could discriminate $S$. monacanthus SOFRI from dragon fruits in other countries.

The maturase mat $\mathrm{K}$ is one of the fastest evolving genes in the chloroplast genome. It was widely applied for phylogenetic studies at the species level since it played a crucial role in the RNA splicing process (SchmitzLinneweber et al. 2015). The utility of mat $\mathrm{K}$ region tested for species-level identification on 528 species of Cactaceae, including approximately $75 \%$ of Mexican species. Yesson et al. (2011) find that the DNA barcode by matK could identify exactly $77 \%$ of collected species. However, the expectation value is more than that percentage, and the change of nucleotides in primer regions is the main 
drawback for PCR specificity of such gene (Yesson et al. 2011). Bell et al. (2017) generated the $r b c \mathrm{~L}$ database for the identification of plant mixture. This study succeeded in accurate species-level identification for eight angiosperm species: Populus tremuloides (Salicaceae), Populus deltoides, Broussonetia papyrifera (Moraceae), Carya illinoinensis (Juglandaceae), Bassia scoparia (Amaranthaceae), Ambrosia artemisiifolia (Asteraceae), Artemisia tridentata (Asteraceae), Poa pratensis (Poaceae) and a family-level identification of Zea mays (Poaceae). Thus, the $r b c \mathrm{~L}$ gene should be an improvement on ITS, a nuclear sequence has been utilized widely for plant identification. The $r b c \mathrm{~L}$ (1, 5-ribulose bisphosphate carboxylase/oxygenase large subunit) gene encodes a large subunit of rubisco protein, which is an important enzyme for photosynthesis (Fangru et al. 2020). Thus, matK and $r b c \mathrm{~L}$ were responsible for key metabolism processes in cells, so the changes of their sequences might be powerful markers for species identification.

Frequent plant hybridization via mechanisms such as polyploidy and various breeding systems have given rise to new hybrids formation (Fazekas et al. 2012). Several breeding programs were submitted to increase the yield and quality of dragon fruits lead to high intra- and interspecific hybridization. This phenomenon generated taxonomical confusion, leading to the complexity of dragon fruit species and varieties (Jian-ye et al. 2021). Therefore, a single locus possesses insufficient discrimination power to identify these species. In this study, the $S$. monacanthus SOFRI variety was authenticated by three loci, atpF-H $+r b c \mathrm{~L}+$
matK. Several studies contributed that species resolution was improved significantly by multiple loci. Data from 12 plant genera showed that chloroplast genome sequences are highly variable, and such regions should be the priority when seeking the suitable loci to resolve closely related plant species or varieties and for DNA barcoding (Dong et al. 2012). The utilization of multiple loci considers as a potential solution for accurate identification (Fazekas et al. 2012; Wu et al. 2017). A single DNA barcode only identifies some of the 18 species in the Melilotus genus, a herbal plant in North Africa. According to these findings, the combination of five loci, $m a t \mathrm{~K}+r b c \mathrm{~L}+\operatorname{trn} \mathrm{L}-\mathrm{F}+\operatorname{trn} \mathrm{H}-$ $p s b \mathrm{~A}+$ ITS showed the greatest species resolution while the single $r b c \mathrm{~L}$ was the least. Khan et al. (2017) reported that four coding regions $m a t \mathrm{~K}, r b c \mathrm{~L}, r p o \mathrm{~B}$, and $r p o \mathrm{C} 1$ were highly conservative among the taxa. On the other hand, the sequences of two intergenic spacers $p s b \mathrm{~K}-p s b \mathrm{I}$ and $a t p \mathrm{~F}-a t p \mathrm{H}$ were variable, specifically identifying the medicinal plant Rhazya stricta (Khan et al. 2017). Gogoi and Bhau (2018) indicated that single-locus ITS or combined with plastid matK expressed the better species authentication of the genus Nepenthes based on barcoding gaps. Vu et al. (2020) also suggested that the combination of ITS + matK was the most potential DNA barcode for Vietnamese Paphiopedilum species. Therefore, It was reasonable to conclude that reliable identification was strongly supported by more than one DNA barcode locus. Last but not least, an effective locus for this species may have some limitations for another species.

Table 8. Single nucleotide polymorphisms (SNPs) and indel mutations of matK gene

\begin{tabular}{|c|c|c|c|c|c|c|c|c|c|c|}
\hline \multirow{2}{*}{$\begin{array}{c}\text { Accession } \\
\text { number }\end{array}$} & \multirow{2}{*}{ Sample } & \multicolumn{9}{|c|}{ Positions } \\
\hline & & 738 & 784 & 787 & 799 & 800 & 801 & 809 & 817 & 826 \\
\hline OK094529 & DF1 & $\mathbf{A}$ & $\mathbf{A}$ & $\mathbf{A}$ & & $\mathbf{A}$ & $\mathbf{T}$ & - & $\mathbf{A}$ & $\mathbf{A}$ \\
\hline OK094530 & DF2 & . & . & . & $\overline{\mathbf{G}}$ & . & . & - & . & . \\
\hline OK094531 & DF3 & . & C & . & A & $\mathbf{T}$ & G & $\overline{\mathbf{G}}$ & . & . \\
\hline OK094532 & DF4 & . & . & . & _ & . & . & - & . & . \\
\hline OK094533 & DF5 & . & . & . & - & . & . & - & - & . \\
\hline OK094534 & DF6 & . & . & . & - & . & . & - & - & - \\
\hline OK094535 & DF7 & . & . & . & - & . & . & $\overline{\mathbf{A}}$ & - & - \\
\hline OK094536 & DF8 & . & . & . & - & . & . & - & . & - \\
\hline OK094537 & DF9 & - & $\dot{0}$ & 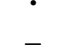 & - & $\dot{0}$ & . & - & $\dot{.}$ & . \\
\hline OK094538 & DF10 & . & . & . & - & . & . & - & . & . \\
\hline
\end{tabular}

Note: DF1: S. monacanthus SORFI; DF2: S. monacanthus BT, DF3: S. monacanthus CM; DF4: Selenicereus sp.; DF5: Selenicereus sp. SORFI; DF6: S. undatus BT; DF7: S. undatus CM; DF8: S. megalanthus DT; DF9: S. megalanthus TG; DF10: Selenicereus sp. AG

Table 9. Nucleotide polymorphism between Selenicereus monacanthus SOFRI and other Selencicereus species on NCBI database

\begin{tabular}{|c|c|c|c|c|c|}
\hline Locus & Length (nt) & Coverage $(\%)$ & Identities (\%) & Number of gaps & Accessions \\
\hline atpF-H & 576 & 100 & 97.61 & 9 & S. undatus (NC_053698.1) \\
\hline \multirow{4}{*}{ mat K } & 782 & 100 & 99.74 & 0 & S. tricae (LT745724.1) \\
\hline & & & & & S. undatus (NC 053698.1) \\
\hline & & & & & S. peruvianus (AY015310.1) \\
\hline & & & & & S. ocamponis (LT745687.1) \\
\hline \multirow[t]{2}{*}{$r b c \mathrm{~L}$} & 506 & 100 & 99.41 & 2 & S. costaricensis (JQ590992.1) \\
\hline & & & & & S. undatus (NC_053698.1) \\
\hline rpoC1 & 452 & 100 & 100 & 0 & S. undatus (NC 053698.1) \\
\hline
\end{tabular}


This study successfully constructed DNA barcodes data for common Selenicereus species in the Mekong delta, consisting of four chloroplast loci: $r b c \mathrm{~L}, r p o \mathrm{C} 1, \operatorname{mat} \mathrm{K}$ and atpF-H. Such sequences showed high PCR yield and specificity as well as sequence quality. The rpoC1 region was not a suitable barcode for this plant because of the highly conservative sequence. Based on the appearance of SNPs and indel mutations, three loci: $r b c \mathrm{~L}, m a t \mathrm{~K}$ and $a t p \mathrm{~F}$ $\mathrm{H}$ were able to distinguish some species. The integration of these three loci enhances the discrimination power and the successful identification of $S$. monacanthus DF1 varieties.

\section{ACKNOWLEDGEMENTS}

Tran Gia Huy, VINIF.2020.ThS.68 was funded by Vingroup Joint Stock Company and supported by the Domestic Master/ PhD Scholarship Programme of Vingroup Innovation Foundation (VINIF), Vingroup Big Data Institute (VINBIGDATA)".

\section{REFERENCES}

Abirami K, Swain S, Baskaran V, Venkatesan K, Sakthivel K, Bommayasamy N. 2021. Distinguishing three Dragon fruit (Hylocereus spp.) species grown in Andaman and Nicobar Islands of India using morphological, biochemical and molecular traits. Sci Rep 11: 2894. DOI: $10.1038 / \mathrm{s} 41598-021-81682-\mathrm{x}$

Bell KL, Loeffler VM, Brosi BJ. 2017. An $r b c$ L reference library to aid in the identification of plant species mixtures by DNA metabarcoding. Appl Plant Sci 5 (3): 1600110. DOI: 10.3732/apps.1600110

Cisneros A, Tel-Zur N. 2012. Evaluation of interspecific-interploid hybrids (F1) and back crosses (BC1) in Hylocereus species (Cactaceae). In: Andrew S (ed) Meiosis: Molecular mechanisms and cytogenetic diversity. InTechOpen, Croatia. DOI: 10.5772/32435

DeSalle R, Goldstein P. 2019. Review and interpretation of trends in DNA barcoding. Front Ecol Evol 7: 302. DOI: 10.3389/fevo.2019.00302

Dong W, Liu J, Yu J, Wang L, Zhou S. 2012. Highly variable chloroplast markers for evaluating plant phylogeny at low taxonomic levels and for DNA barcoding. PloS one 7 (4): e35071. DOI: 10.1371/journal.pone.0035071

Fangru N, Yuxin H, Xudong L, Jia F, Junping L, Qi L, Shulian X. 2020. Analysis of adaptive evolution and coevolution of $r b c \mathrm{~L}$ gene in the Genus Hildenbrandia (Rhodophyta). Evol Bioinform 16: 1176934320977862. DOI: 10.1177/1176934320977862

Fazekas AJ, Kuzmina ML, Newmaster SG, Hollingsworth PM. 2012. DNA barcoding methods for land plants. In: DNA Barcodes. Humana Press, Totowa. DOI: 10.1007/978-1-61779-591-6_11

Gómez-Hinostrosa C, Hernández HM, Terrazas T, Correa-Cano ME. 2014. Studies on Mexican Cactaceae. V. Taxonomic notes on Selenicereus tricae. Brittonia 66 (1): 51-59. DOI: 10.1007/s12228013-9308-y

Gogoi B, Bhau BS. 2018. DNA barcoding of the genus Nepenthes (Pitcher plant): A preliminary assessment towards its identification. BMC Plant Biol 18: 153. DOI: 10.1186/s12870-018-1375-5

Huong NTT, Hung NQ, Lu DV, Khanh TD. 2021. Morphological characteristics and genetic diversity of some red dragon fruit samples in field trials and matK marker sequencing. J Sci Engineer Res 8 (1): 189-195.

Jian-ye C, Fang-fang X, Yan-ze C, Can-bin C, Wang-jin L, Xiao-di H, Yong-hua Q. 2021. A chromosome-scale genome sequence of pitaya (Hylocereus undatus) provides novel insights into the genome evolution and regulation of betalain biosynthesis. Hortic Res 8: 164. DOI: 10.1038/s41438-021-00612-0

Köhler M, Reginato M, Souza-Chies TT, Majure LC. 2020. Insights into chloroplast genome evolution across Opuntioideae (Cactaceae) reveals robust yet sometimes conflicting phylogenetic topologies. Front Plant Sci 11: 729. DOI: 10.3389/fpls.2020.00729

Korotkova N, Borsch T, Arias S. 2017. A phylogenetic framework for the Hylocereeae (Cactaceae) and implications for the circumscription of the genera. Phytotaxa 327 (1): 1-46. DOI: 10.11646/phytotaxa.327.1.1

Khan SA, Baeshen MN, Ramadan HA, Baeshen NA. 2017. Emergence of plastidial intergenic spacers as suitable DNA barcodes for arid medicinal plant Rhazya stricta. Am J Plant Sci 8 (8): 1774-1789. DOI: 10.4236/ajps.2017.88121

Kress WJ. 2017. Plant DNA barcodes: Applications today and in the future. J Syst Evol 55: 291-307. DOI: 10.1111/jse.12254

Kumar S, Stecher G, Li M, Knyaz C, Tamura K. 2018. MEGA X: Molecular evolutionary genetics analysis across computing platforms. Mol Biol Evol 35 (6): 1547. DOI: 10.1093/molbev/msy096

Ibrahim SRM, Milborne P, Mohamed GA, Khedr AIM, Zayed MF, El-Kholy AAES. 2018. Genus Hylocereus: Beneficial phytochemicals, nutritional importance, and biological relevance-A review. J Food Biochem 42 (2): e12491. DOI: 10.1111/jfbc.12491

Montoya-Arroyo A, Schweiggert RM, Pineda-Castro ML, Sramek M, Kohlus R, Carle R, Esquivel P. 2014. Characterization of cell wall polysaccharides of purple pitaya (Hylocereus sp.) pericarp. Food Hydrocolloids 35: 557-564. DOI: 10.1016/j.foodhyd.2013.07.010

Paśko P, Galanty A, Zagrodzki P, Ku YG, Luksirikul P, Weisz M, Gorinstein S. 2021. Bioactivity and cytotoxicity of different species of pitaya fruits - A comparative study with advanced chemometric analysis. Food Biosci 40: 100888. DOI: 10.1016/j.fbio.2021.100888

Qin Q, Li J, Zeng S, Xu Y, Han F, Yu J. 2021. The complete plastomes of red fleshed pitaya (Selenicereus monacanthus) and three related Selenicereus species: Insights into gene losses, IR expansions and phylogenomic implications. Research Square. DOI: 10.21203/rs.3.rs373541/v1

Santos C, Pereira F. 2018. Identification of plant species using variable length chloroplast DNA sequences. Forensic Sci Int Genet 36: 1-12. DOI: 10.1016/j.fsigen.2018.05.009

Schmitz-Linneweber C, Lampe MK, Sultan LD, Ostersetzer-Biran O. 2015. Organellar maturases: A window into the evolution of the spliceosome. Biochimica et Biophysica Acta (BBA)-Bioenergetics 1847 (9): 798-808. DOI: 10.1016/j.bbabio.2015.01.009

Tao J, Qiao G, Wen XP, Gao GL, Liu T, Peng ZJ. 2014. Characterization of genetic relationship of dragon fruit accessions (Hylocereus spp.) by morphological traits and ISSR markers. Sci Hortic 170: 82-88. DOI: 10.1016/j.scienta.2014.03.006

Tenore GC, Novellino E, Basile A. 2012. Nutraceutical potential and antioxidant benefits of red pitaya (Hylocereus polyrhizus) extracts. J Funct Foods 4 (1): 129-136. DOI: 10.1016/j.jff.2011.09.003

Viñas M, Jiménez VM. 2016. Occurrence and characterization of calcium oxalate crystals in stems and fruits of Hylocereus costaricensis and Selenicereus megalanthus (Cactaceae: Hylocereeae). Micron 89: 21 27. DOI: $10.1016 /$ j.micron.2016.07.002

Vu HT, Vu QL, Nguyen TD, Tran N, Nguyen TC, Luu PN. 2020. Genetic diversity and identification of Vietnamese Paphiopedilum species using DNA Sequences. Biology 9 (1): $9 . \quad$ DOI: 10.3390/biology9010009

Wichienchot S, Jatupornpipat M, Rastall RA. 2010. Oligosaccharides of pitaya (dragon fruit) flesh and their prebiotic properties. Food Chem 120 (3): 850-857. DOI: 10.1016/j.foodchem.2009.11.026

Wu F, Ma J, Meng Y, Zhang D. 2017. Potential DNA barcodes for Melilotus species based on five single loci and their combinations. PLoS One 12 (9): e0182693. DOI: 10.1371/journal.pone.0182693

Yesson C, Barcenas RT, Hernandez HM, Ruiz-Maqued MDe L, Prado A, Rodriguez VM, Hawkins JA. 2011. DNA barcodes for Mexican Cactaceae, plants under pressure from wild collecting. Mol Ecol Resour 11 (5): 775-783. DOI: 10.1111/j.1755-0998.2011.03009.x 